\title{
Pengembangan Media Kobaki pada Materi Perkalian dan Pembagian untuk Siswa Kelas II Sekolah Dasar
}

\author{
Dwi Virgo Mulia Asmara ${ }^{1}$, Dedi Kuswandi ${ }^{2}$, Abdur Rahman As'ari ${ }^{3}$ \\ ${ }^{1}$ Pendidikan Dasar-Universitas Negeri Malang \\ ${ }^{2}$ Teknologi Pendidikan-Universitas Negeri Malang \\ ${ }^{3}$ Pendidikan Matematika-Universitas Negeri Malang
}

INFO ARTIKEL
Riwayat Artikel:
Diterima: $14-05-2020$
Disetujui: $21-12-2020$
Kata kunci:
mathematics learning;
kobaki medium;
multiplication and division;
pembelajaran matematika;
media kobaki;
perkalian dan pembagian

\section{Alamat Korespondensi:}

Dwi Virgo Mulia Asmara

Pendidikan Dasar

Universitas Negeri Malang

Jalan Semarang 5 Malang

E-mail: virgoodvelvi@gmail.com

\begin{abstract}
ABSTRAK
Abstract: The type of research used is R\&D adaptation from Dick and Carey. The aim is to determine the level of feasibility, attractiveness, and effectiveness of product development. The product is the kobaki media for second grade elementary school learning for multiplication and distribution materials. The subjects involved in the research were students from grades $2 \mathrm{~A}$ and 2B of the Muhammadiyah 4 Elementary School in Batu City. The procedures and steps used for the study used the procedures and steps of the Puslitjaknov Team which consisted of five activity steps. From the data obtained from research for the kobaki media, the criteria are quite decent. very interesting, and very effective to use.
\end{abstract}

\begin{abstract}
Abstrak: Jenis penelitian yang digunakan yaitu R \& D adaptasi dari Dick and Carey. Tujuannya untuk mengetahui tingkat kelayakan, kemenarikan, dan keefektifan produk pengembangan. Produk tersebut adalah media kobaki untuk pembelajaran kelas dua sekolah dasar untuk materi perkalian dan pembagian. Untuk subjek yang terlibat dalam penelitian tersebut merupakan siswa dari kelas 2A dan 2B Sekolah Dasar Muhammadiyah 4 Kota Batu. Prosedur dan langkah yang digunakan untuk penelitian tersebut menggunakan prosedur dan langkah dari Tim Puslitjaknov yang terdiri dari lima langkah kegiatan. Dari data yang diperoleh dari penelitian untuk media kobaki mendapatkan kriteria cukup layak. sangat menarik, dan sangat efektif untuk digunakan.
\end{abstract}

Pendidikan adalah usaha dalam memengaruhi peserta didik yang dilakukan secara sadar supaya dapat mengembangkan segala potensinya yang bermanfaat untuk dapat menjalani hidup dengan sebaik-baiknya (Utama, 2011). Tujuan dari pendidikan yaitu membantu peserta didik supaya bisa meningkatkan potensi yang dimilikinya. Proses kegiatan belajar mengajar umumnya dilakukan secara formal, yaitu kegiatan pembelajaran yang dilakukan di sekolah yang melibatkan interaksi antara pengejar dan pembelajar. Untuk setiap pembelajaran yang dilakukan secara formal, setiap pengajar diharuskan dapat mengidentifikasikan karakter dari setiap pelajarnya yang berguna untuk mendapatkan pembelajaran yang berkesan (Othman \& Othman, 2004). Dalam setiap kegiatan pembelajaran yang dilakukan tidak hanya dapat melibatkan interaksi antara pengajar dan pembelajar, akan tetapi melibatkan unsur-unsur yang sangat berpengaruh lainnya antara lain sumber belajar, alat peraga/media, sarana, dan prasarana (Su'udiah, Degeng, \& Kuswandi, 2016). Unsur-unsur tersebut antara satu dengan lainnya saling berkaitan. Kegiatan belajar mengajar tidak akan berjalan dengan maskimal jika unsur dari penunjang pembelajaran tersebut tidak terpenuhi. Untuk memenuhi hal itu maka dibutuhkan proses pendidikan yang bermakna dan berkualitas. Faktor penunjang tercapainya pendidikan yang berkualitas yaitu seberapa mampu guru dalam mengelola pengalaman belajar yang diciptakan. Pengalaman belajar yang berkualitas tersebut dapat diperoleh dari kesesuaian antara hasil belajar dengan apa yang menjadi tujuan dari pembelajaran (Rahman, 2018). Untuk mendapatkan pendidikan yang berkualitas tersebut yaitu dengan cara menciptakan kegiatan pembelajaran yang tepat dan menarik.

Dalam kegiatan belajar mengajar, terdapat pembelajaran matematika yang diterapkan. Mata pelajaran matematika adalah mata pelajaran yang diajarkan disemua tingkatan sekolah, dari jenjang sekolah dasar sampai di tingkatan perguruan tinggi (Susanto, 2013). Pembelajaran matematika merupakan penunjang tercapainya keberhasilan dalam mempelajari mata pelajaran yang lain. Matematika merupakan ilmu pasti, yaitu induk atau sumber dari segala ilmu pengetahuan yang ada (Halim, 2009). Setiap individu harus memiliki ilmu pengetahuan yang digunakan dalam mengembangkan pribadi yang berkompeten yang berguna sebagai tiang utama dalam pembangunan nasional (Wahyuni, Djatmika, \& As'sari, 2018). Dari alasan di atas menggambarkan untuk pembelajaran matematika memiliki peranan yang sangat penting dalam membentuk karakter berpikir 
siswa yang berkualitas. Konsep dan prinsip dari pembelajaran matematika digunakan akan membantu siswa dalam mengkaji suatu secara sistematis, kreatif, dan logis. Untuk materi pada pembelajaran matematika terdapat operasi hitung, seperti pengurangan, penjumlahan, perkalian, dan pembagian sehingga matematika dapat dikatakan ilmu hitung dan ilmu pasti.

Umur siswa untuk tingkatan SD antara 7-12 tahun berada pada tahap perkembangan operasi konkret (Piaget dalam Dworetzky, 1990). Dalam tahap tersebut kemampuan pemahaman dan pemecahan masalah bersifat nyata dan konkret. Kemampuan yang dimiliki siswa untuk menyelesaikan suatu permasalahan pada umumnya tidak sama, terdapat siswa yang berkemampuan sedang, tinggi, maupun rendah (Aini, Purwanto, \& Sa'dijah, 2016). Ketertarikan peserta didik dalam mengikuti jalannya kegiatan belajar mengajar bisa dipengaruhi dari kemampuan pengajar dalam menjelaskan materi maupun kemampuan dalam menggunakan media pembelajaran (Arifudin, Kuswandi, \& Soepriyanto, 2019). Dalam pelaksanaan kurikulum 2013 guru harus mempersiapkan segala sumber dan sarana untuk memperoleh suasana belajar mengajar yang berkesan, selain itu dalam proses belajar mengajar diharapkan dapat dilakukan dengan cara mempraktikan secara langsung (Pratama, Ulfa, \& Kuswandi, 2018). Pembelajaran yang inovatif harus bisa diciptakan oleh guru untuk memancing semangat belajar dari peserta didik sehingga untuk kegiatan belajar mengajar yang dilaksanakan bisa tercapai secara optimal (Yuliandari \& Wahjudi, 2014). Suatu kegiatan pembelajaran yang optimal dapat dilihat dari banyaknya siswa yang terlibat di dalam pembelajaran. Untuk mencapai suatu keberhasilan dalam kegiatan pembelajaran, bukan dari faktor metode saja, melainkan juga perangkat pembelajaran yang digunakan (Tjiptiany, As'ari, \& Muksar, 2016). Penyusunan perangkat pembalajaran harus dilakukan guru sebelum dimulainya proses pembelajaran sehingga untuk tujuan pembelajaran yang diinginkan dapat tercapai (Hidayati, As'ari, \& Candra, 2016). Perangkat pembelajaran merupakan satu diantara beberapa faktor untuk menentukan keberhasilan kegiatan pembelajaran (Safrida, As'ari, \& Sisworo, 2016).

Dalam pelaksanaan kegiatan belajar mengajar bukan guru dan siswa saja yang terlibat, tetapi unsur penujang lainnya, seperti sumber, media, sarana, dan prasarana (Su'udiah, Degeng, \& Kuswandi, 2016). Sekarang ini merupakan era dunia media, dimana kegiatan belajar mengajar dituntut banyak mempergunkan media pembelajaran dan dikuranginya metode ceramah. Dalam pelaksanaan kegiatan belajar mengajar keterampilan proses dan aktif learning sangat ditekankan, maka dari itu peranan penggunaan dari media sangat diperlukan dalam pembelajaran (Nurseto, 2011). Arti media dalam pembelajaran adalah alat peraga yang berguna dalam menyampaikan pesan dari pengajar ke siswa untuk mencapai tujuan yang diharapkan (Widodo \& Wahyudin, 2018). Oleh karena itu, dapat dikatakan bahwa media adalah perantara dalam menyampaikan pesan dari pemberi ke penerima (Ratnawati, Rokhima, Tjendrowaseno, 2013). Pemakaian media untuk pembelajaran sangat berguna bagi guru untuk mempermudah penyampaian materi yang diajarkan untuk merangsang siswa bisa mengikuti jalannya kegiatan pembelajaran secara aktif dan penuh semangat (Chabib, Djatmika, \& Kuswandi, 2017). Proses bepikir siswa yang abstrak/sulit dapat disederhanakan apabila dalam pembelajaran menggunakan media (Sudjana \& Rivai, 2015). Penggunaan media dalam pembelajaran akan membuat pembelajaran itu sendiri akan menjadi kegiatan pembelajaran yang tepat dan menarik. Untuk menghasilakn media yang efektif digunakan dalam pembelajaran maka dalam pembuatan dan penggunaan media dapat dirancang secara sistematis dan sebaik mungkin (Melinda, Degeng, \& Kuswandi, 2017). Pemanfaatan media untuk kegiatan belajar mengajar adalah faktor penunjang keberhasilan belajar siswa (Buchori \& Setyawati, 2015). Kriteria media yang berkualitas merupakan media yang dapat menyampaikan pesan secara tepat (Pratama, Ulfa, \& Kuswandi, 2018). Maka dari itu dalam pembuatan dan penggunaan media perlu adanya keseuaian antara materi dan media yang digunakan supaya materi yang disampaikan bisa diterima dan bertahan lama pada ingatan siswa (Wulandari, Susilo, \& Kuswandi, 2016).

Berdasarkan hasil observasi, SD Muhammadiyah 4 Batu adalah sekolah yang berkualitas baik dan unggul di Kota Batu. SD Muhammadiyah 4 Batu juga merupakan sekolah yang terakreditasi A dan berhasil meraih beberapa prestasi di tingkat daerah maupun provinsi. Di Kota Batu untuk SD Muhammadiyah 4 adalah satu dari beberapa sekolah yang dijadikan percontohan pelaksanaan kurikulum tahun 2013. Selain itu, untuk tenaga pendidiknya juga sering mengikuti kegiatan KKG yang diadakan oleh pemerintah daerah setempat. Namun meskipun demikian, ternyata masih ada sejumlah guru yang mengajarkan perkalian dan pembagian dengan metode yang kurang tepat. Siswa diminta untuk menghafal perkalian dan pembagian saja. Akibatnya, pengetahuan siswa terhadap perkalian dan pembagian hanya sebatas hafalan saja. Mereka tidak memahami konsep dari operasi hitung perkalian dan pembagian. Untuk perkalian bisa dikatakan sebagai penjumlahan yang diulang-ulang sedangkan untuk pembagian adalah proses pengurangan secara berulang. Cara untuk mengatasi permasalahan perkalian dan pembagian di SD adalah dengan melaksanakan pembelajaran berbasis konstruktivis. Ciri pembelajaran berbasis konstruktivis adalah meminta siswa untuk selalu pro aktif dalam kegiatan pembelajaran. Untuk mengaktifkan proses pembelajaran tersebut maka solusinya dengan memakai media dalam pembelajaran.

Media kobaki (kotak bagi kali) adalah media yang dipakai untuk kegiatan belajar mengajar yang menyajikan cara berhitung perkalian dan pembagian dengan menggunakan kotak yang berbentuk balok dan menggunakan bola bekel. Dengan menggunakan media pembelajaran kobaki ini peserta didik lebih dipermudah dalam mempelajari perkalian dan pembagian dengan memasukkan bola bekel ke dalam kotak yang sudah disediakan. Adapun kelebihan dari media kobaki, meliputi (1) media terbuat dari bahan yang aman untuk siswa dan ramah lingkungan, (2) pengoperasian media sederhana, praktis, dan mudah digunakan, (3) media dapat dipergunakan peserta didik dalam pembelajaran di luar lingkungan sekolah, (4) media bisa dimobilisasi dengan mudah, (5) berat/massa media proporsional bagi siswa, (6) media tidak membahayakan siswa dalam penggunaan/ pengoperasian media, (7) ukuran media secara keseluruhan proporsional untuk siswa kelas II sekolah dasar, (8) penggunaan gambar karakter hewan dan warna sesuai dengan karakter siswa kelas II sekolah dasar, dan (9) tampilan media 
secara keseluruhan menarik perhatian siswa. Pembuatan media kobaki itu sendiri menggunakan mika transparan yang dilapisi kain flanel yang tentunya memiliki tingkat keamanan yang baik bagi anak usia sekolah dasar. Selain itu, bentuk dari media kobaki ini didesain dengan sebaik-baiknya yang disesuaikan dengan karakteristik anak usia SD. Bukan hanya itu saja, untuk media kobaki yang digunakan, siswa mendapatkan pengalaman secara langsung dalam menentukan hasil hitung dari perkalian dan pembagian.

Penelitian terdahulu yang sesuai dengan pengembangan media pembelajaran kobaki guna membantu siswa dalam proses pembelajaran sekaligus dapat meningkatkan kualitas pembelajaran. Untuk yang pertama penelitian dari Ringgana Rizki Romadhoni (2016) menujukkan bahwa hasil belajar dan minat belajar siswa menjadi meningkat setelah menggunakan media pembelajaran papan stik. Untuk yang kedua penelitian dari Samar Solehan (2016), menunjukkan untuk hasil belajar siswa menggunakan media papan geomultiplikasi menjadi meningkat, hal itu dipengaruhi karena siswa sangat berantusias, bersemangat dalam menggunakan media tersebut sehingga minat belajar siswa menjadi meningkat. Kemudian penelitian dari M. Rohman Farisnanda (2016), penggunaan media bisa meningkatkan hasil belajar siswa. Perolehan hasil data untuk $X_{2}$ lebih tinggi dari $X_{1}(89,1>71)$, dengan itu perolehan skor post-test lebih besar dibandingkan pre-test. Selanjutnya, Delia Indrawati dan Siti Partini Suardiman (2013) menunjukkan untuk media yang dikembangkan tersebut efektif untuk dipakai dalam mata pelajaran matematika materi pembagian dan perkalian bilangan pecahan untuk kelas V sekolah dasar. Skor data yang didapat thitung $=-9,764$ untuk itu H0 ditolak, maka dapat diketahui untuk skor rata-rata post-test lebih tinggi dibanding skor pre-test. Suharmanto (2014) menunjukkan $90 \%$ dari total sampel penelitian dapat menerima dan merasakan manfaat dari penggunaan media pembelajaran papan hitung pembagian. Manfaat utama yang didapat siswa dari penggunaan media pembelajaran papan hitung pembagian tersebut yaitu mempercepat dan mempermudah proses berhitung pembagian.

Berdasarkan permasalah yang ditemukan di lapangan maka peneliti mempunyai beberapa alasan dipilihnya media pembelajaran kobaki untuk dikembangkan. Beberapa pertimbangan tersebut, (1) mempermudah dalam penyampaian materi, (2) meningkatkan keefisiensian kegiatan pembelajaran yang dilakukan (3) menciptakan semangat dan minat, (4) membentuk meningkatkan konsentrasi anak dalam belajar, (5) mendorong anak supaya dapat belajar mandiri, dan (6) menimbulkan dan menciptakan pengalaman pembelajaran yang sama. Urgensi dalam penelitian ini yaitu mempermudah dan membantu siswa untuk lebih gampang memahami konsep dari pembagian dan perkalian yang ada di kelas II sekolah dasar. Adapun konsep perkalian itu sendiri yaitu merupakan penjumlahan yang berulang, sedangkan untuk pembagian merupakan pengurangan yang berulang. Produk pengembangan media pembelajaran kobaki tersebut diharapkan dapat dipergunakan guru untuk menyelesaikan permasalahan keterbatasan media yang ada.

\section{METODE}

Dalam penelitian ini untuk jenis penelitiannya menggunakan Research and Development (R\&D). Jenis penelitian tersebut adalah sebuah strategi maupun metode yang dipergunakan untuk menghasilkan/mendapat suatu produk (Sugiyono, 2010). Penelitian dan pengembangan mempunyai arti yaitu suatu prosedur maupun langkah yang digunakan untuk memperbaiki produk yang telah ada ataupun membuat suatu produk baru yang bisa dipertanggung jawabkan. Jenis penelitian Research and Development adalah salah satu jenis penelitian yang dipergunakan dalam pengembangan produk yang berorientasi pada dunia pendidikan. Adapun tujuan dari penelitian, yaitu memudahkan guru untuk menyampaikan materi-materi yang diarjakan dengan lancer dan jelas. Di dalam dunia pendidikan, penelitian R \& D tersebut juga berfungsi dalam meningkatkan keefektifan suatu kegiatan belajar mengajar baik saat proses maupun hasilnya sehingga tujuan dari pembelajaran dapat tercapai. Dalam proses pengembangan produk yang dilakukan melewati berbagai prosedur dan aturan yang sudah ditetapkan yang beracuan dan sesuai prosedur sehingga dapat menghasilkan produk yang sempurna. Sementara itu, untuk model pengembangannya menggunakan Borg \& Gall. Untuk model pengembangan yang disampaikan Borg \& Gall merupakan strategi yang digunakan dalam mengembangkan suatu produk melalui proses dan prosedur yang telah ditentukan guna mendapatkan standar kelayakan. Karakteristik yang dimiliki antara model pengembangan Borg and Gall dan penelitian R\&D yaitu salah satu model prosedural yang bersifat deskriptif untuk menghasilkan produk. Adapun didalam prosedurnya ada 10 langkah yaitu (1) pengumplan data awal, (2) perencanaan, (3) pengembangan format produk awal, (4) uji coba lapangan awal, (5) validasi produk, (6) revisi produk, (7) uji coba lapangan, (8) revisi produk akhir, (9) uji pelaksanaan lapangan, dan (10) diseminasi dan implementasi.

Di dalam kegiatan penelitian untuk kesepuluh langkah tersebut bersifat tidak baku, namun jika kesepuluhnya dilaksanakan akan menghasilkan produk yang bias dipertanggung jawabkan (Sukmadinata dalam Anwar et al., 2017). Kesepuluh langkah tersebut bisa disederhanakan menjadi lima langkah utama, yaitu (1) analisis produk, (2) pengembangan produk awal, (3) validasi dari ahli, (4) ujicoba skala kecil, dan (5) ujicoba skala besar (Tim Puslitjaknov, 2008). Untuk langkah dan prosedur tersebut dijelaskan pada gambar 1 . 


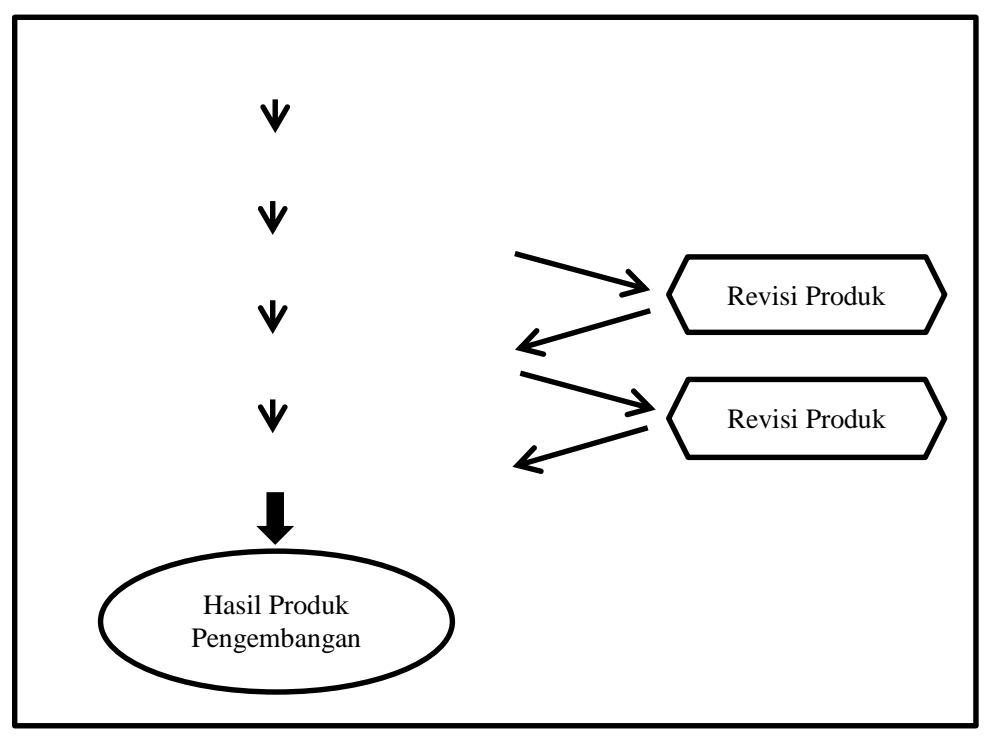

Gambar 1. Prosedur Pengembangan

\section{HASIL}

Pada kegiatan analisis produk yang dillakukan, ditemukan permasalahan berupa keterbatasan penggunaan media untuk membantu kelancaran kegiatan pembelajaran yang dilakukan. Untuk selanjutnya peneliti membuat rancangan awal dari media yang akan dikembangkan. Setelah rancangan media tersebut jadi maka dilakukan validasi. Kegiatan validasi yang dilakukan tersebut bertujuan untuk mendapatkan data dari ahli. Data dan informasi yang diperoleh dari para validator nantinya digunakan dalam menentukan kevalidan media tersebut. Apabila materi dan media belum mendapatkan kriteria kelayakan, maka akan direvisi sesuai dengan saran dari para ahli. Untuk validator materi dan validator media pembelajaran kobaki tersebut merupakan Dosen Matematika di Universitas Negeri Malang. Tingkat kelayakan ataupun kevalidan produk yang dihasilkan didapat melalui instrumen angket validasi. Rumus yang digunakan dalam perhitungan hasil validasi tersebut yaitu sebagai berikut.

$$
\mathrm{V}=\frac{\text { Jumlah TSEV }}{\text { Jumlah } \mathrm{T}-\mathrm{Smax}} \mathrm{X} 100 \%
$$

Keterangan:

V : Validitas

TSEV : Total skor validator

T-Smax : Skor maksimal

Kriteria kualitas produk dapat menggunakan kriteria kelayakan/validitas. Krtiteria pencapaian kelayakan produk menentukan keualifikasi produk dan penentuan perlunya diadakan revisi atau tidak perlu revisi, dapat digunakan atau tidak dapat digunakan. Kriteria kelayakan/validitas produk media pembelajaran dan petunjuk penggunaannya ditunjukkan pada tabel 1.

\section{Tabel 1. Kriteria Kelayakan/Validitas Produk}

\begin{tabular}{ccl}
\hline Persentase Pencapaian & Kategori & \multicolumn{1}{c}{ Keterangan } \\
\hline $86-100 \%$ & Sangat valid & Bisa dipergunakan tanpa revisi \\
$70-85 \%$ & Cukup valid & Bisa dperigunakan dengan revisi kecil \\
$60-69 \%$ & Kurang valid & Kurang layak dipergunakan, disarankan untuk tidak digunakan \\
$0-59 \%$ & Tidak valid & Tidak dapat digunakan \\
\hline
\end{tabular}

Penilaian uji validitas materi diberikan kepada ahlinya yaitu ahli dibidang matematika yang bertujuan untuk memperoleh tingkat kevalidan materi. Validator dari materi merupakan Dosen Matematika di Universitas Negeri Malang. Peneliti menyerahkan angket validasi materi beserta media kobaki dan petunjuk penggunaan kepada validator. Skor yang diperoleh dijelaskan pada tabel 2. 
Tabel 2. Skor Perolehan Validasi Materi

\begin{tabular}{|c|c|c|c|c|c|}
\hline No & Pernyataan & TSEV & Smax & $\mathbf{P}(\%)$ & Tingkat Kevalidan \\
\hline 1 & $\begin{array}{l}\text { Materi yang dibahas sesuai dengan KI, KD, dan Indikator Kurikulum } 2013 \text { kelas II SD } \\
\text { Semester I }\end{array}$ & 4 & 5 & $80 \%$ & Cukup Valid \\
\hline 2 & $\begin{array}{l}\text { Materi yang dibahas sesuai dengan tujuan pembelajaran dalam kurikulum } 2013 \text { kelas II } \\
\text { SD Semester I }\end{array}$ & 4 & 5 & $80 \%$ & Cukup Valid \\
\hline 3 & Materi yang dibahas sesuai dengan perkembangan siswa kelas II SD & 4 & 5 & $80 \%$ & Cukup Valid \\
\hline 4 & Materi yang dibahas melalui media kobaki mudah dipahami siswa kelas II SD & 4 & 5 & $80 \%$ & Cukup Valid \\
\hline 5 & $\begin{array}{l}\text { Materi yang dibahas melalui media kobaki sesuai dengan konteks kehidupan siswa } \\
\text { kelas II SD }\end{array}$ & 4 & 5 & $80 \%$ & Cukup Valid \\
\hline 6 & $\begin{array}{l}\text { Materi yang dibahas melalui media kobaki merangsang } \\
\text { rasa ingin tahu siswa }\end{array}$ & 5 & 5 & $100 \%$ & Sangat Valid \\
\hline 7 & Materi yang dibahas melalui media kobaki membangkitkan semangat belajar siswa & 5 & 5 & $100 \%$ & Sangat Valid \\
\hline 8 & Tujuan pembelajaran melalui media kobaki jelas & 4 & 5 & $80 \%$ & Cukup Valid \\
\hline 9 & Pembelajaran melalui media kobaki sesuai Indikator pembelajaran & 4 & 5 & $80 \%$ & Cukup Valid \\
\hline 10 & Pembelajaran melalui media kobaki sesuai dengan materi pembelajaran & 4 & 5 & $80 \%$ & Cukup Valid \\
\hline 11 & Jenis soal evaluasi pembelajaran sesuai dengan materi. & 4 & 5 & $80 \%$ & Cukup Valid \\
\hline & TOTAL & 46 & 55 & $84 \%$ & Cukup Valid \\
\hline
\end{tabular}

Dari skor perolehan validasi materi tersebut bisa kita lihat untuk persentase kevalidannya yaitu 84\%. Apabila dikonversikan pada tabel skala tingkat kevalidan, maka untuk persentase $84 \%$ berada pada tingkat kualifikasi cukup valid. Dari hal tersebut maka tingkat kelayakan yang dimiliki media pembelajaran kobaki memiliki tingkat kelayakan yang cukup tinggi. Maka dari itu media pembelajaran kobaki layak untuk digunakan untuk kegiatan belajar mengajar. Kemudian hasil yang didapat dari validasi kepada ahli media bahwa media kobaki ini mempunyai tingkat kevalidan yang cukup valid. Pernyataan tersebut dapat dibenarkan dari nilai yang telah didapat dari validator yaitu sebesar78. Maka dari skor 78 tersebut apabila dikonversikan pada tabel skala tingkat kevalidan media pembelajaran kobaki tersebut memiliki tingkat kevalidan sebesar $82 \%$. Maka dapat dikatakan media pembelajaran kobaki tersebut memiliki tingkat kevalidat cukup valid. Perolehan skor validasi media dipaparkan pada tabel 3 .

Tabel 3. Skor Perolehan Validasi Media

\begin{tabular}{|c|c|c|c|c|c|}
\hline No & Pernyataan & TSEV & Smax & $\mathbf{P}(\%)$ & Tingkat Kevalidan \\
\hline 1 & Media dapat digunakan dengan mudah & 4 & 5 & $80 \%$ & Cukup Valid \\
\hline 2 & Pengoperasian media sederhana dan praktis & 4 & 5 & $80 \%$ & Cukup Valid \\
\hline 3 & Media dapat digunakan siswa dalam pembelajaran di luar lingkungan sekolah & 5 & 5 & $100 \%$ & Sangat Valid \\
\hline 4 & Media terbuat dari bahan yang ramah lingkungan & 4 & 5 & $80 \%$ & Cukup Valid \\
\hline 5 & Media dapat dimobilisasi dengan mudah & 4 & 5 & $80 \%$ & Cukup Valid \\
\hline 6 & Pewarna yang digunakan aman untuk siswa & 4 & 5 & $80 \%$ & Cukup Valid \\
\hline 7 & Berat/massa media proporsional bagi siswa & 4 & 5 & $80 \%$ & Cukup Valid \\
\hline 8 & Media tidak membahayakan siswa dalam penggunaan/ pengoperasian media & 4 & 5 & $80 \%$ & Cukup Valid \\
\hline 9 & Media sesuai dengan karakter siswa kelas II SD & 5 & 5 & $100 \%$ & Sangat Valid \\
\hline 10 & Media sesuai dengan kompetensi dasar siswa kelas II SD & 4 & 5 & $80 \%$ & Cukup Valid \\
\hline 11 & $\begin{array}{l}\text { Petunjuk penggunaan media menggunakan Bahasa Indonesia yang baik dan } \\
\text { benar }\end{array}$ & 4 & 5 & $80 \%$ & Cukup Valid \\
\hline 12 & Petunjuk penggunaan media mudah dipahami oleh siswa kelas II SD & 4 & 5 & $80 \%$ & Cukup Valid \\
\hline 13 & Media menggunakan bahan yang aman untuk anak usia SD & 4 & 5 & $80 \%$ & Cukup Valid \\
\hline 14 & Penggunaan warna sesuai dengan karakter siswa kelas II SD & 4 & 5 & $80 \%$ & Cukup Valid \\
\hline 15 & $\begin{array}{l}\text { Ukuran huruf pada petunjuk penggunaan media sesuai dengan karakter siswa } \\
\text { kelas II SD }\end{array}$ & 4 & 5 & $80 \%$ & Cukup Valid \\
\hline 16 & Ukuran media secara keseluruhan proporsional untuk siswa kelas II SD & 4 & 5 & $80 \%$ & Cukup Valid \\
\hline 17 & Tampilan media secara keseluruhan menarik perhatian siswa & 4 & 5 & $80 \%$ & Cukup Valid \\
\hline 18 & Media sesuai dengan materi pembelajaran & 4 & 5 & $80 \%$ & Cukup Valid \\
\hline 19 & Media memperjelas materi pembelajaran & 4 & 5 & $80 \%$ & Cukup Valid \\
\hline & TOTAL & 78 & 95 & $82 \%$ & Cukup Valid \\
\hline
\end{tabular}

Berdasarkan nilai yang didapatkan dari validasi produk yang telah dilakukan, maka media kobaki dapat digunakan dengan perbaikan/revisi kecil terlebih dahulu. Perbaikan terhadap produk dilakukan dengan memberikan penambahan gambargambar hewan pada bagian samping dan belakang media. Selain itu, pemilihan gambar hewan juga dibuat berwarna-warni. Hal tersebut bertujuan agar media kobaki terlihat lebih menarik. Hasil dari revisi media dapat kobaki dilihat pada tabel 4. 
Tabel 4. Revisi Produk

\begin{tabular}{|c|c|c|c|}
\hline No & Bagian yang Direvisi & Sebelum Direvisi & Sesudah Direvisi \\
\hline \multirow[t]{2}{*}{1.} & $\begin{array}{l}\text { Bagian samping kanan media kobaki yang masih kosong } \\
\text { diberi gambar, seperti gambar-gambar hewan. }\end{array}$ & & \\
\hline & & $\begin{array}{l}\text { Gambar 2. Bagian kanan media } \\
\text { kobaki sebelum direvisi }\end{array}$ & $\begin{array}{l}\text { Gambar 3. Bagian kanan } \\
\text { media kobaki sesudah direvisi }\end{array}$ \\
\hline \multirow[t]{2}{*}{3} & $\begin{array}{l}\text { Bagian samping kiri media kobaki yang masih kosong } \\
\text { diberi gambar, seperti gambar-gambar hewan. }\end{array}$ & & \\
\hline & & $\begin{array}{l}\text { Gambar 4. Bagian kiri media } \\
\text { kobaki sebelum direvisi }\end{array}$ & $\begin{array}{l}\text { Gambar 5. Bagian kiri media } \\
\text { kobaki sesudah direvisi }\end{array}$ \\
\hline & $\begin{array}{l}\text { Bagian belakang media kobaki yang masih kosong diberi } \\
\text { gambar, seperti gambar-gambar hewan. }\end{array}$ & & \\
\hline & & $\begin{array}{l}\text { Gambar 6. Bagian belakang media } \\
\text { kobaki sebelum direvisi }\end{array}$ & $\begin{array}{l}\text { Gambar } 7 \text {. Bagian belakang } \\
\text { media kobaki sesudah direvisi }\end{array}$ \\
\hline
\end{tabular}

Setelah melakukan validasi materi dan validasi produk pada ahli media, kemudia dilakukan kegiatan uji coba skala kecil. Kegiatan tersebut bertujuan guna mendapatkan data kemenarikan produk dari media kobaki. Dalam uji coba tersebut dilaksanakan terhadap siswa kelas IIA SD Muhammadiyah 4 Batu sejumlah 6 siswa. Responden ujicoba skala kecil diatas dipilih secara acak sesuai masukan yang didapat dari guru kelas II A. Dari hasil validasi media yang dilakukan terhadap enam siswa kelas II A tersebut, dapat dikatakan bahwa media kobaki memiliki kualifikasi menarik. Hal ini dibuktikan dengan jumlah skor yang diberikan siswa terhadap media kobaki yaitu sebesar 584 dengan persentase sebesar 97\%. Dengan demikian, media kobaki memiliki tingkat kemenarikan sangat menarik dan dapat digunakan tanpa melakukan revisi. Untuk skor yang didapat dari ujicoba skala kecil dijelaskan pada tabel 5.

Tabel 5. Skor Perolehan Ujicoba Skala Kecil

\begin{tabular}{clcc}
\hline No & \multicolumn{1}{c}{ Nama } & Validitas & Kualifikasi \\
\hline 1 & Aghnina Rachma & 98 & Menarik \\
2 & Almetha Fitri Pramesti & 100 & Menarik \\
3 & Lail Rivano Mukti A. C & 94 & Menarik \\
4 & Mochammad Kaffah F & 96 & Menarik \\
5 & Shireen Anggi Deby A & 100 & Menarik \\
6 & Sima Sahira & 96 & Menarik \\
\hline & $\quad$ Skor total & 584 & Menarik \\
\hline & Persentase skor & $97 \%$ & Menarik, dapat digunakan tanpa revisi \\
\hline
\end{tabular}

Apabila media pembelajaran sudah diperbaiki dan layak untuk dipergunakan, untuk selanjutnya media tersebut akan digunakan dalam kegiatan ujicoba skala besar yang pelaksanaannya diterapkan dilakukan di kelas II B SD Muhammadiyah 4 Batu yang berjumlah sebanyak 25 siswa. Pada tahap ini dilakukan kegiatan (pre-tes dan post-test). Tujuan dilakukannya uji coba lapangan yaitu untuk mengetahui tingkat keefektifan media pembelajaran kobaki tersebut. Responden uji coba lapang tersebut yaitu siswa siswi kelas II B SD Muhammadiyah 4 Batu yang berjumlah sebanyak 25 siswa. Dalam kegiatan ini yang bertindak sebagai observer yaitu guru wali kelas II B dan teman dari peneliti. Untuk memperoleh data hasil belajar siswa, uji coba dilaksanakan dalam 2 tahap. Untuk tahap yang kesatu dilakukan di kelas kontrol, dan tahap kedua dilakukan pada kelas eksperimen yaitu setelah menggunakan media (post-test). Pengukuran hasil belajar dilaksanakan dengan cara siswa diberikan lembar evaluasi pada siswa. Data hasil uji coba pada kelas kontrol dan kelas eksperimen disajikan pada tabel 6. 
Tabel 6. Skor Perolehan Uji Coba Skala Besar

\begin{tabular}{|c|c|c|c|}
\hline \multirow{2}{*}{ No } & \multirow{2}{*}{ Nama Responden } & \multicolumn{2}{|c|}{ Nilai } \\
\hline & & Pretest & Postest \\
\hline 1 & Adam Cahyana Abidin & 70 & 80 \\
\hline 2 & Adinda Hawa Mayori & 65 & 80 \\
\hline 3 & Afrika Bima Putra Al Kharim & 60 & 70 \\
\hline 4 & Alif Savi Syauqi & 70 & 80 \\
\hline 5 & Alyssa Syfa Rahmawati & 70 & 80 \\
\hline 6 & Arkan Ghifari Imansyah & 60 & 70 \\
\hline 7 & Asyifa Naima Prayogo & 75 & 90 \\
\hline 8 & Azahra Kanza Aquila & 75 & 80 \\
\hline 9 & Bella Oktavia & 70 & 85 \\
\hline 10 & Bintang Fajar Dewata & 75 & 90 \\
\hline 11 & Fachira Nayfa Mardya Rafeyla & 75 & 85 \\
\hline 12 & Haify Archie Albigaly & 70 & 80 \\
\hline 13 & Khariza & 75 & 80 \\
\hline 14 & Kanaya Derisha & 70 & 85 \\
\hline 15 & Nabila Nur Arkhana & 80 & 85 \\
\hline 16 & Na'ilah Aqila Ibnah Sya'ban & 75 & 85 \\
\hline 17 & Naura Putri & 70 & 75 \\
\hline 18 & Nigel Agvalza Titryan Falasta & 75 & 90 \\
\hline 19 & Raditya Rajendra Putra W & 70 & 80 \\
\hline 20 & Raihana Tiffany Avrillia Putri & 55 & 75 \\
\hline 21 & Raja' Ghiffary Abiyah Taqiy & 55 & 75 \\
\hline 22 & Rafael Nayaka Revikanza & 70 & 85 \\
\hline 23 & Seto Suryo Atmojo & 75 & 85 \\
\hline 24 & Sifa Nabila Keysa P. S & 75 & 80 \\
\hline 25 & Stefano Vicky Alviansyah & 55 & 75 \\
\hline & Skor total & 1735 & 2025 \\
\hline & Rata-rata & 69 & 81 \\
\hline & ersentase ketuntasan belajar & $76 \%$ & $100 \%$ \\
\hline
\end{tabular}

Berdasarkan sajian data yang ada di atas bahwa diketahui ada perbedaan antara nilai rata-rata siswa pada kelas kontrol dan kelas eksperimen. Nilai rata-rata pada kelas kontrol sebesar 69, sedangkan pada kelas eksperimen rata-rata nilainya sebesar 81. Persentase ketuntasan belajar siswa pada kelas kontrol sebesar $76 \%$ dan persentase ketuntasan belajar siswa pada kelas eksperimen sebesar $100 \%$. Dari data yang diperoleh tersebut menunjukkan nilai yang didapat siswa mengalami kenaikan setelah malaksanakan pembelajaran mempergunakan media kobaki. Maka dari itu, dapat dikatakan untuk media kobaki sangat efektif untuk digunakan. Dari serangkaian uji coba yang sudah dilaksanakan, dapat disimpulkan bahwa untuk media kobaki sudah memenuhi kriteria kevalidan, menarik, dan efektif untuk digunakan dalam kegiatan belajar mengajar. Dengan demikian, taraf keberhasilan pembelajaran dengan menggunakan media pembelajaran kobaki sangat baik.

\section{PEMBAHASAN}

Data yang diperoleh dalam tahap analisis produk merupakan data yang didapat dari studi pustaka yang berhubungan dengan penelitian. Data tersebut dipergunakan dalam pengembangan produk awal. Karena di penelitian tersebut sampel yang diambil merupakan kelas II sekolah dasar untuk itu peneliti mencari berbagai macam jenis data yang didapat dengan cara observasi di kelas maupun wawancara secara langsung kepada guru kelas II. Setelah itu masuk di tahap kedua yaitu mengembangkan produk awal, dalam tahap ini bahan maupun alat evaluasi pembelajaran disiapkan oleh peneliti. Untuk produk yang dihasilkan nantinya yaitu dalam bentuk benda (hardware). Produk tersebut berupa media kobaki dengan desain awal berdasarkan desain dari peneliti itu sendiri. Tahap yang selanjutnya yaitu uji validasi ahli. Dalam tahap ini materi dan media divalidasikan kepada para ahli. Dari data yang didapat dari validasi untuk media kobaki yang dikembangkan tersebut memiliki tingkat kevalidan cukup valid yaitu dengan memperoleh skor $84 \%$ dan $82 \%$. Apabila dikonversikan pada tabel skala tingkat kevalidan, maka untuk persentase $84 \%$ mendapatkan tingkat kevalidan cukup valid. Untuk tingkat kevalidan tersebut tercapai karena adanya kesesuaian tujuan dan materi pembelajaran (Susilana \& Riyana, 2008).

Selain itu, adanya kesesuaian media dengan tujuan dan materi belajar yang dicapai. Maka dari itu media kobaki memiliki tingkat kelayakan yang cukup tinggi untuk diterapkan di dalam kegiatan belajar mengajar. Tahap selajutnya yaitu kegiatan ujicoba skala kecil. Pada kegiatan uji coba kelompok kecil tersebut diikuti sebanyak enam siswa. Perolehan data dalam kegiatan tersebut diketahui bahwa presentase kemenarikan produk dari media kobaki sebesar 97\%. Maka dari itu media kobaki memiliki tingkat kemenarikan yang cukup tinggi untuk diterapkan dalam kegiatan pembelajaran. Pada tahap selanjutnya yaitu pelaksanaan uji coba kelompok besar. Dalam tahap tersebut apabila media pembelajaran sudah dilakukan perbaikan, maka 
untuk selanjutnya media tersebut siap untuk dipergunakan dalam kelompok besar yang dilaksanakan di kelas II B SD Muhammadiyah 4 Batu yang berjumlah 25 siswa. Dalam tahapan ini diberlakukan kelas kontrol (pre-test) dan kelas eksperimen (post-test). Berdasarkan data dari ujicoba skala besar diketahui terdapat perbedaan nilai antara kelas kontrol dan kelas eksperimen. Untuk kelas kontrol nilai rata-rata yang didapat yaitu 69, kemudian nilai rata-rata yang didapat dalam kelas ekseperimen yaitu 81. Untuk presentase ketuntasan belajar yang diperoleh dari kelas kontrol yaitu 76\%, sedangkang untuk ketuntasan belajar yang diperoleh dari kelas eksperimen yaitu 100\%. Dari hal tersebut dapat diketahui untuk hasil belajar siswa dalam kegiatan pembelajaran menggunakan media kobaki dapat meningkatkan. Dengan demikian taraf keberhasilan pembelajaran dengan menggunakan media pembelajaran kobaki sangat efektif. Selain dari hasil belajar siswa, tingkat keefektifan media juga diperoleh dari hasil kegiatan observasi. Dari hasil observasi tersebut bisa diketahui untuk media kobaki tersebut memiliki kriteria sangat efektif, dengan perolehan persentase sebesar $90 \%$. Kegiatan belajar mengajar menjadi lebih dinamis dan siswa bisa terlibat secara aktif mengoperasikan media sehingga pembelajaran matematika menjadi efektif. Keefektifan media dalam pembelajaran ditunjukkan oleh keefektifan dan hasil belajar siswa. Kegiatan siswa dalam mengoperasikan media kobaki menuntun siswa memperoleh pengalaman langsung dalam menemukan hasil perkalian dan pembagian. Dalam melakukan kegiatan pembelajaran matematika, sangat perlu untuk mempergunakan alat peraga yang berfungsi untuk meningkatkan pemahaman siswa (Subanji, 2012). Media kobaki memiliki bentuk dan berat yang dinamis sehingga mudah dimobilisasi dari tempat satu ketempat yang lain.

\section{SIMPULAN}

Dari hasil data yang didapatkan dari proses validasi, bisa diketahui untuk kedua uji validasi tersebut masing-masing memiliki tingkat kevalidan cukup valid. Untuk hasil validasi materi mendapatkan skor 46 dengan presentase kevalidan sebesar $84 \%$. Sedangkan untuk hasil validasi media medapatkan skor 78 dengan presentase kevalidan sebesar 82\%. Tahap ujicoba skala kecil dipergunakan untuk medapatkan data tingkat kemenarikan dari produk yang dikembangkan. Ujicoba skala kecil dilaksanakan dengan cara memberikan angket kepada siswa kelas II A sejumlah 6 siswa yang dipilih secara random sesuai data yang diberikan langsung oleh guru kelas II A. Perolehan data dari ujicoba skala kecil menunjukkan untuk skor yang diberikan siswa terhadap media kobaki yaitu sebesar 584 dengan persentase sebesar 97\%. Maka dengan presentase sebesar $97 \%$ media kobaki memiliki kulifikasi menarik. Dengan demikian, media kobaki dapat digunakan tanpa melakukan revisi.

Keefektifan produk pengembangan media kobaki dapat diukur dengan menerapkan kelas kontrol (pre-test) dan kelas eksperimen (post-test). Perolehan data dari kegiatan tersebut menunjukkan untuk nilai pre-test mendapatkan skor sebesar 69 sedangkan pada kegiatan pos-test medapatkan skor sebesar 81. Kemudian untuk presentase ketuntasan belajar siswa itu sendiri pada saat pre-test sebesar $76 \%$ sedangkan untuk persentase ketuntasan belajar saat post-test mendapatkan persentase sebesar 100\%. Dari data tersebut bisa diketahui terdapat peningkatan hasil belajar siswa setelah menggunakan media kobaki dalam pembelajaran. Dari perolehan skor dan persentase yang telah didapat media pembelajaran kobaki yang telah digunakan memiliki taraf keberhasilan sangat baik. Penggunaan media kobaki perlu pendampingan guru untuk memberikan bimbingan dan pengarahan terhadap siswa saat menemukan kendala atau kesulitan dalam pengoperasiannya.

\section{DAFTAR RUJUKAN}

Aini, K. N., Purwanto, \& Sa'dijah, C. (2016). Proses Koneksi Matematika Siswa Berkemampuan Tinggi dan Rendah dalam Memecahkan Masalah Bangun Datar. Jurnal Pendidikan: Teori, Penelitian, dan Pengembangan, 1(3), 377-388.

Anwar, M. F. N., Ruminiati., \& Suharjo. (2017). Pengembangan Modul Pembelajaran Tematik Terpadu Berbasis Kearifan Lokal Kabupaten Sumenep Kelas IV Subtema Lingkungan Tempat Tinggalku. Jurnal Pendidikan: Teori, Penelitian, dan Pengembangan, 2(10), 1291-1297.

Arifudi, A., Kuswandi, D., \& Soepriyanto, Y. (2019). Pengembangan Media Objek 3 Dimensi Digital Sel Hewan dan Tumbuhan Memanfaatkan Piramida Hologram untuk MTS. Jurnal Kajian Teknologi Pendidikan, 2(1), 9-15.

Buchori, A., \& Setyawati, R. D. (2015). Development Model of Character Education Through E-Comic in Elementary School. International Journal of Education and Research, 3(9), 369-386.

Chabib, M., Djatmika, E. T., \& Kuswandi, D. (2017). Efektivitas Pengembangan Media Permainan Ular Tangga Sebagai Sarana Belajar Tematik SD. Jurnal Pendidikan: Teori, Penelitian, dan Pengembangan, 2(7), 910-918.

Dworetzky, J. P. (1990). Introduction to Child Development. Minnesota: Western Publishing House.

Halim, A. F. (2009). Matematika Hakikat \& Logika. Yogyakarta: AR-Ruzz Media.

Hidayati, D., As'ari, A. R., \& Candra, T. D. (2016). Pengembangan Perangkat Pembelajaran Berbasis Pemecahan Masalah untuk Meningkatkan Kemampuan Berpikir Kritis Siswa SMP Kelas IX. Jurnal Pendidikan: Teori, Penelitian, dan Pengembangan, 1(4), 634-649.

Melinda, V, A., Degeng, I. N. S., \& Kuswandi, D. (2017). Pengembangan Media Video Pembelajaran IPS Berbasis Virtual Field Trip (VFT) Pada Kelas V SDNU Kraton-Kencong. Jurnal Inovasi dan Teknologi Pembelajaran, 3(2), $158-164$.

Nurseto, T. (2011). Membuat Media Pembelajaran yang Menarik. Jurnal Ekonomi dan Pendidikan, 8(1), 19-35.

Othman, N., \& Othman, S. R. (2004). Gaya Pembelajaran Kolb dalam Mata Pelajaran Biologi. Jurnal Teknologi, 40(1), 45-58.

Pratama, R. A., Ulfa, S., \& Kuswandi, D. (2018). Mobile Learning Berbasis Game Based Learning Pelajaran Matematika Pokok Bahasan Bangun Ruang Sisi Datar. Jurnal Pendidikan: Teori, Penelitian, dan Pengembangan, 3(6), 771-777. 
Ratnawati, Rokhima. Tjendrowaseno, T. I. (2013). Pembuatan Media Pembelajaran Biologi untuk Kelas VIII Sekolah Menengah Pertama Negeri 1 Tasikmadu. Seminar Riset Unggulan Nasional Informatika dan Komputer FTI UNSA Maret.

Safrida, L. N., As'ari, A. R., \& Sisworo, S. (2016). Pengembangan Perangkat Pembelajaran Berbasis Problem Solving Polya Untuk Meningkatkan Kemampuan Penalaran Matematis Siswa Materi Peluang Kelas XI SMA. Jurnal Pendidikan: Teori, Penelitian, dan Pengembangan, 1(4), 583-591.

Suarjana, I. M., Nanci Riastini, N. P., \& Yudha Pustika, I. G. N. (2017). Penerapan Pendekatan Kontekstual Berbantuan Media Konkret Untuk Meningkatkan Aktivitas dan Hasil Belajar. International Journal of Elementary Education. https://doi.org/10.23887/ijee.v1i2.11601

Sudjana, N \& Rivai, A. 2015. Media Pengajaran: Buku yang Memudahkan Guru dalam Memilih, Merancang, dan Menggunakan Media Pengajaran. Bandung: Sinar Baru Algesindo.

Sugiyono. 2010. Metode Penelitian Kuantitatif Kualitatif dan R\&D. Bandung: Alfabeta.

Susanto, A. 2013. Teori Belajar dan Pembelajaran di Sekolah Dasar. Jakarta: Kencana Prenadamedia Group.

Susilana, R., \& Riyana, C. 2008. Hakekat, Pengembangan, Pemanfaatan, dan Penilaian. Bandung: CV Wacana Prima

Su'udiah, F., Degeng, I., \& Kuswandi, D. (2016). Pengembangan Buku Teks Tematik Berbasis Kontekstual. Jurnal Pendidikan: Teori, Penelitian, dan Pengembangan, 1(9), 1744-1748.

Tjiptiany, E., As'ari, A., \& Muksar, M. (2016). Pengembangan Modul Pembelajaran Matematika dengan Pendekatan Inkuiri untuk Membantu Siswa SMA Kelas X dalam Memahami Materi Peluang. Jurnal Pendidikan: Teori, Penelitian, dan Pengembangan, 1(10), 1938-1942.

Utama, A. M. B. (2011). Pembentukan Karakter Anak Melalui Aktivitas Bermain Dalam Pendidikan Jasmani. Jurnal Pendidikan Jasmani Indonesia, 8(1), 1-9.

Wahyuni, P. D., Djatmika, E. T., \& As'sari, A. R. (2018). Pengaruh Full Day School dan Gerakan Literasi Sekolah terhadap Hasil Belajar dengan Mediasi Motivasi Belajar. Jurnal Pendidikan: Teori, Penelitian, dan Pengembangan, 3(5), $679-684$.

Widodo, S. A., \& Wahyudin. (2018). Selection of Learning Media Mathematics for Junior School Students. TOJET: Turkish Online Journal of Educational Technology, 17(1), 154-160.

Wulandari, R., Susilo, H., \& Kuswandi, D. (2016). Multimedia Interaktif Bermuatan Game Edukasi sebagai Salah Satu Alternatif Pembelajaran IPA di Sekolah Dasar. Jurnal Pendidikan: Teori, Penelitian, dan Pengembangan, 2(8), 10241029.

Yuliandari, S \& Wahjudi, E. (2014). Pengembangan Media Pembelajaran Berbasis Multimedia Interaktif pada Mata Pelajaran Ekonomi Materi Jurnal Penyesuaian Perusahaan Jasa. Jurnal Pendidikan Akuntansi, 2(2), 1-9. 